Univerzitet u Beogradu
Poljoprivredni fakultet
Institut za poljoprivrednu tehniku
Naučni časopis
POLJOPRIVREDNA TEHNIKA
Godina XLIV
Broj 3, 2019.
Strane: $59-68$

UDK: 631.6.

Originalni naučni rad

\title{
EFFECT OF DRYING METHOD ON FUNCTIONAL PROPERTIES OF YAM (Dioscorea sp.) FLOUR
}

\author{
Chineze G. Okeke ${ }^{1 *}$, Sylvester. I Oluka ${ }^{1}$ \\ ${ }^{I}$ Department of Agricultural \& Bioresource Engineering \\ Enugu State University of Science and Technology, \\ Enugu State, Nigeria
}

\begin{abstract}
The effect of drying method on functional properties of five different yam flour varieties namely, white yam, purple yam, yellow yam, water yam and three leaves yam were studied using oven, solar and sun drying method. The functional properties were determined using AACC approved method. Results revealed that White yam recorded wettability range of $173.22-181.31$ secs while the purple yam had wettability range from 151.69 to 201 secs, the three leave Yam, had wettability range from 138.41 to 190.20 secs, the water yam and yellow yam recorded wettability range from 143.62 to 182.11 secs and 153.42 to 174.34 secs respectively. Result also indicated that white yam recorded water absorption capacity (WAC) range from134.32 to 146.11, while purple yam had WAC range from 134.32 to 145.46; three leave Yam, water yam and yellow yam recorded from 129.56 to 138.11 , from 133.58 to 163.21 and from 128.34 to 143.88 respectively. Furthermore, white yam, purple yam, three leave yam, water yam and yellow yam respectively recorded swelling power range from 11.84 to 12.63 , from 11.14 to 11.82 , from 11.28 to 12.66 , from 12.19 to 12.38 and from 11.68 to 11.96 . The three leave yam recorded the highest water absorption capacity which makes it likely to have least shelf life stability as compared to others because of the ability of absorbing water from a humid atmosphere. Results of the analysis of variance (ANOVA) on the effect of drying methods on the functional properties of the yam varieties showed significant difference at $5 \%$ and $1 \%$ probability level while the yam varieties did not show any significant different on the functional properties of the yam flour varieties.
\end{abstract}

Key words: Drying method, functional properties, yam flour, wettability, absorption capacity.

\footnotetext{
*Correspond Author. E-mail address: chinezeglory@yahoo.com
} 


\section{INTRODUCTION}

Yam is a tuberous crop with great economic value in the whole world especially tropical West African region. It belongs to the family Dioscoreaceae and genus Dioscorea that produce tubers and bulbils or rhizomes. Among many other species of Dioscorea genus the following are of economic importance, Dioscorea rotundata, Dioscorea alata, Dioscorea Cayenesis, Dioscorea esculenta, Dioscorea dumentorum, Dioscorea bulbifera, Dioscorea trifida, Dioscorea opposita and Dioscorea japonica. However, among these species only Dioscorea rotundata, Dioscore aalata, Dioscorea esculenta, Dioscorea cayenesis, Dioscorea dumentorum and Dioscorea bulbifera are edible [1].

Yams are broadly distributed all over the world, but their circulation concentrated more in the tropical regions. It forms an important crop and food source for tropical countries such as; West Africa, West Indies, East African, America, China, Japan, Philippines, Madagascar, Southeast Asia, South Caribbean, Malaysia, South Pacific Island, Korea and Papua New Guinea [2]. In most of these countries, yam constitutes a good portion of the source of dietary calories of their population, while in some countries like; Japan and China, yam contributes significantly to their industrial raw materials, especially in the areas of pharmaceutical and brewery industries. They have extended to production of non-grain ethanol as an alternative to fuel using yam, cassava and potato [3]. According to FAO [4], the trend of global yam production states that Africa account for about $96 \%$ of world production of yam, with Nigeria alone being responsible for nearly three quarters of the world total production; $73.8 \%$ of African total production, 35.017 million metric tonnes/year [5]. According to report of IITA [6], most of the world and African yam production is concentrated in the "yam belt" starting from Cote d'Ivoire, through Ghana then Togo, Cameroon and Nigeria, where yam is not just a food security crop but an indigenous food crop that is harmonized into socio-cultural lives of the people. Nigeria is the largest producer of yams in the world, accounting for over $76 \%$ percent of the world production [7]. IITA [7] reported that more than 2.8 million hectares of land is under yam cultivation annually in Nigeria.

Yam tubers can be processed using different methods. It could be dried and processed into yam flour. Yam is one of the common staple foods in Nigeria. It could be used in making livestock feed and in industrial starch production [8], [9]. It is one of the major tuber crops making impact in the Nigeria economy, in terms of capacity and value of production

Functional properties provide relevant information on the behaviour of components of food products during processing, such information is very vital in the successful incorporation of unconventional food ingredients in the existing food formulation. Blending one flour with another flour might result in some technology difficulties which can impair the qualities of the product [10]. The dough properties play vital role in the quality of baked products whereas the visco-elastic properties of the flour are also a source of understanding of the dough handling behaviour in the preparation of bakery products [11].

Some vital functional properties are water absorption capacity (WAC), oil absorption capacity, water binding capacity (WBC), swelling power (SWP) emulsification and solubility. 
WAC refers to the total amount of water held by a starch gel under a specific state or condition. It is therefore a measure of the ability of the food product to entrap large amount of water such that exudation is prevented [12]. Previous works on WAC of starch based food materials indicate that it is highly dependent on crystalline properties of starch [13]. Sittu et al. [14] in their work on the functional properties of baking flour reported that baking quality is a function of WAC of the flour whereas Jackel [15] maintained that flour with increased WAC would result in favorable characteristics of final product as the product will remain soft for a longer period with improvement in texture and reduced cost. Ezeocha et al. [16] also reported that WAC is affected by the size and shape of starch -based food product as well as the presence of protein, lipids and salts in such food while WBC is affected by the presence of minerals like phosphorus. Abiodun and Akinoso [17] further observed in their work on the functional properties of trifoliate yam that the water absorption capacity, solubility and swelling power were more dependent on pre-treatment methods than the harvesting periods and drying methods.

Swelling power which is a measure of the maximum increase in volume and weight undergone by the starch granules when they are allowed to freely swell in water is an indicator of the strength of the hydrogen bonding between the granules [18]. Rasper [19] explained that the swelling and solubilisation characteristics of various starches which are indicators of strenght of the miscellular network within the starch granules affect its rheological properties. He further noted that the ability of starch granules to swell and yield a viscous paste has been the most important practical properties of starch because of its effect on the rheological behaviour. WBC is a measure of the associative force between the starch granules of food ingredients. It is indicator of the magnitude of the molecular surface of the starch granules available for binding with water molecules [20]; [21].The aim of this research work is to obtain useful data on the functional properties of some selected varieties of yam flour which will guide food manufacturer/ processors in yam processing and preservation.

\section{MATERIALS AND METHOD}

\section{Research Materials}

The research materials include five varieties of yam tubers namely; white yam (Dioscorea rutundata), purple yam (Dioscore alata), yellow yam (Dioscorea cayenensis), three leaves yam (Dioscorea bulbifera) and water yam (Dioscorea alata), which were obtained from Anambra State Agricultural Development Programme (ANADEP) at harvest moisture content range from 56.8 to $65 \%$ wb.

\section{Drying Equipment}

Three different drying methods/ equipment were used for the study. They include an Electric oven dryer of model LOA 1805 Munich Germany; A solar dryer (solar energy Collector) locally fabricated, it was made of metallic box having gross dimensions. 
The gross dimensions of the absorber plate are $1.0 \mathrm{~m}$ long, $0.62 \mathrm{~m}$ wide and $0.55 \mathrm{~mm}$ thickness with a net surface area of $0.62 \mathrm{~m}^{2}$. The solar collector was covered with one layer clear glass of $3 \mathrm{~mm}$ thickness to reduce the reflection of radiation and heat losses by convection. The solar dryer has capacity of $6.38 \mathrm{~m}^{3}$ with the collector efficiency of $63.5 \%$ and system thermal efficiency of $46.77 \%$; and a percentage energy loss of 16.73 $\%$. It was attached with the drying chamber by an air duct which has a cross sectional area of $0.14 \mathrm{~m}^{2}$ and was oriented to face south (where it will get most sunlight) as it was tilt with an optimum tilt angle. The third dryer is natural sun drying (open Air) open space spread with black nylon (so as to be absorbing heat).

\section{Experimental Procedure \\ Sample preparation}

The yam tubers were washed, hand-peeled and sliced to range of 10 to $15 \mathrm{~mm}$ thickness. Each variety of the yam tubers after slicing were divided into three sets for use at three different drying methods (oven dryer, sun dryer (open air) and solar dryer) The samples for oven drying was further divided into three for use at three drying temperatures. The sliced yam tubers were generally dried in each case to a constant weight and milled accordingly using laboratory harmer mill. The yam flour was separately kept in moisture resistant/air tight container and was taken to the laboratory for functional and visco-elastic properties tests.

\section{Determination of Wettability}

The wettability of the yam flour was determined following the method described by Onwuka [22] as adopted by Nwosu [23]. A gram of each yam flour sample was placed in a neat, dry measuring cylinder $(10 \mathrm{ml})$. A finger was placed over the open end, the cylinder was inverted and then clamped at a length of $10 \mathrm{~cm}$ from beaker surface $(600 \mathrm{ml}$ beaker) that contains $500 \mathrm{ml}$ of distilled water. The yam flour in the cylinder was slowly spread on the surface of the water at moderate speed. The time it took for each sample to be entirely wet is measured as its wettability.

\section{Water Absorption Capacity (WAC)}

The method as describe by Abey [24] as adopted by Onuegbu, [25]. Each sample was weighed and placed into dry, clean centrifugal tube and both weight noted. $10 \mathrm{ml}$ of distilled water was poured into the tube and properly mixed with the flour to make a suspension. It was then centrifuged at speed of $3500 \mathrm{rpm}$ for $15 \mathrm{~min}$. After which the suspension was discarded, then the tube and its content reweighed and noted. The gain in weight is the water absorption capacity of the test sample.

\section{Determination of the swelling power and solubility of the yam flour}

The swelling power and the solubility of the yam flour were determined using the method of Leach et al [26] as adopted by Eje [27]. In this method, 1g of yam flour sample was weighed into a $50 \mathrm{ml}$ centrifuge tube and water added to give a total volume of $40 \mathrm{ml}$. 
The tube and its contents were heated for 30 mins in water bath at a temperature of $85^{\circ} \mathrm{C}$ with constant stirring. The sample was then centrifuged for 15 min with Hermle 2206A centrifuge of $5 \mathrm{~cm}$ radius at a speed of $2200 \mathrm{rpm}(271 \mathrm{x} \mathrm{g})$ after cooling to a room temperature. The supernatant was poured into a glass crucible and the weight of the sediment noted. The supernatant in the glass crucible was evaporated in an oven at $105^{\circ} \mathrm{C}$ for 24 hours and the residue weighed. The solubility and swelling power were evaluated thus:

$$
\begin{aligned}
& \text { Solubility }(\%)=\frac{\text { weight of residue }}{\text { weight of sample }} \times 100 \\
& \text { Swelling power }(\%)=\frac{\text { weight of sediment }}{\text { Weight of sample }(100-\text { solubility })} \times 100
\end{aligned}
$$

\section{Determination of water binding capacity (WBC)}

The water binding capacity of the yam flour was determined using the method of Sathe and Salunkle [28] as adopted by [27]. In the process, $2 \mathrm{~g}$ of yam flour sample was dissolved in $40 \mathrm{ml}$ of distilled water. The aqueous suspension formed was agitated for 1 hours in a water bath, after which it was centrifuged for 10mins using Hermle $2206 \mathrm{~A}$ centrifuge of $5 \mathrm{~cm}$ radius at $2200 \mathrm{rpm}$. The free water was decanted from the wet sample and drained for $10 \mathrm{~min}$. The water binding capacity was evaluated from the expression.

$$
\text { WBC }(\%)=\frac{\text { bound water }}{\text { weight of sample }} \times 100
$$

\section{RESULTS AND DISCUSSION}

Table 1: Functional characterization of yam flour under three different drying methods.

\begin{tabular}{llccccc}
\hline $\begin{array}{c}\text { Yam } \\
\text { varieties }\end{array}$ & $\begin{array}{c}\text { Drying } \\
\text { method }\end{array}$ & $\begin{array}{c}\text { Wettability } \\
(\text { secs })\end{array}$ & WAC & $\begin{array}{c}\text { WBC } \\
(\%)\end{array}$ & $\begin{array}{c}\text { Solubility } \\
\text { \% }\end{array}$ & $\begin{array}{c}\text { Swelling } \\
\text { power }\end{array}$ \\
\hline White & Oven & 173.22 & 146.11 & 311.4 & 4.82 & 11.92 \\
yam & & & & & & \\
& Sun & 181.31 & 143.83 & 324.6 & 5.93 & 11.84 \\
Purple & Solar & 178.38 & 134.32 & 302.1 & 5.11 & 12.63 \\
yam & Oven & 201.00 & 134.32 & 413.6 & 5.28 & 11.34 \\
& Sun & 191.08 & 141.46 & 361.3 & 4.99 & 11.82 \\
Three & Solar & 151.69 & 145.46 & 393.4 & 4.83 & 11.14 \\
leaves & Oven & 155.00 & 136.33 & 382.1 & 5.92 & 11.28 \\
yam & & & & & & \\
& Sun & 190.20 & 138.11 & 299.1 & 5.66 & 11.98 \\
Water & Solar & 138.41 & 129.56 & 273.4 & 5.09 & 12.66 \\
yam & Oven & 143.62 & 133.58 & 345.2 & 5.28 & 12.38 \\
& Sun & 148.91 & 163.21 & 363.2 & 4.48 & 12.34 \\
Yellow & Solar & 182.11 & 153.30 & 339.5 & 5.22 & 12.19 \\
yam & Oven & 162.37 & 128.34 & 382.6 & 5.21 & 11.68 \\
& & & & & & \\
& Sun & 153.42 & 138.42 & 389.3 & 5.63 & 11.92 \\
& Solar & 174.34 & 143.88 & 335.2 & 5.24 & 11.96 \\
\hline
\end{tabular}


Table 1., presents the functional characteristics of yam flour under three different drying methods. Results of this table revealed that white yam recorded wettability range of $173.22-181.31$ secs. The purple yam had wettability range of $151.69-201$ secs. The three leave yam, had wettability range of $138.41-190.20$ secs. The water yam and yellow yam recorded wettability range of $143.62-182.11$ secs, and $153.42-174.34$ secs respectively. The wettability obtained in the yam varieties are within the range of wettability obtained by Bashirat et al. [1]. Furthermore, white yam recorded water absorption capacity (WAC) range of 134.32 - 146.11, while purple yam had WAC range of 134.32 - 145.46; three leave yam, water yam and yellow yam recorded 129.56 138.11, 133.58 - 163.21 and $128.34-143.88$ respectively. This water absorption capacity obtained for the yam varieties are consistence with the findings of Adedeji [29] in his study of physical, functional and sensory properties of yam flour. White yam also recorded water binding capacity of (WBC) range of $302.1-324.6 \%$, while the purple yam, three leave yam, water yam and yellow yam had WAC of 361.3 - 413.6\%, $273.4-$ $382.1 \%, 339.5-382.6 \%, 273.4-382.1 \%, 339.5-382.6 \%$ and $335.2-389.3 \%$ respectively. In terms of solubility, the white yam had a range of $4.82-5.93$, purple yam $4.83-5.28$, three leave yam 5.09-5.92, water yam and yellow yam had $4.48-5.28$ and $5.21-5.63$ respectively. Then for swallowing power, the white yam, purple yam, three leave yam, water yam and yellow yam respectively recorded $11.84-12.63,11.14$ $11.82,11.28-12.66,12.19-12.38$ and 11.68 11.96.The swelling power of the yam varieties is also in agreement with the findings of Adedeji [29]. Though the yam varieties recoded similar values in their functional properties, there is little variation. Three leaves yam recorded the highest water absorption capacity which makes it likely to have least shelf life stability because of the ability of absorbing water from a humid atmosphere [30]). Sittu et al. [15] reported in their work that WAC determines the baking quality. Jackel [16] reported that flour with high WAC would result to soft product that will remain soft for longer period which is a favorable characteristics of final product with improve texture and lower cost. The functional values of the yam flours shows that they can be used as composite flour to wheat in bakery industry. They also showed that they can yield a soft product which can be appealing to consumers.

Table 2: ANOVA of the effect of drying methods on the functional properties of the yam varieties.

\begin{tabular}{|c|c|c|c|c|c|c|}
\hline Sources of variation & D.f. & $S S$ & $M S$ & F.C al & \multicolumn{2}{|c|}{$F . T a b$} \\
\hline Yam varieties & 4 & -1247130.7 & 311782.7 & $2.93 *$ & $\begin{array}{l}5 \% \\
2.56\end{array}$ & $\begin{array}{c}1 \% \\
3.74\end{array}$ \\
\hline Drying method & 2 & -1247130.7 & 623565.4 & $5.86 * *$ & 3.19 & 5.08 \\
\hline Functionalparameters & 4 & 5911397.6 & 1477849.4 & $13.89 * *$ & 2.56 & 3.74 \\
\hline Error & 49 & -5211397.6 & 106355.1 & & & \\
\hline Total & 59 & -1794261.4 & & & & \\
\hline
\end{tabular}

** Significant at both $1 \%$ and 5\% level of probability; * Significant at only 5\%level of probability.

Table 2 presents the ANOVA of the effect of drying methods on the functional properties of the yam varieties. Results of the analysis showed significant difference at $5 \%$ and $1 \%$ probability level while the yam varieties did not show any significant different on the functional properties of the yam varieties. 


\section{CONCLUSION}

Based on the findings from the study, the following conclusion can be made about the study:

1. White yam recorded wettability range of $173.22-181.31 \mathrm{secs}$. The purple yam had wettability range of $151.69-201$ secs. The three leave yam, had wettability range of $138.41-190.20$ secs. The water yam and yellow yam recorded wettability range of $143.62-182.11$ secs and $153.42-174.34$ secs, respectively.

2. White yam recorded water absorption capacity (WAC) range of 134.32 146.11, while purple yam had WAC range of 134.32 - 145.46; three leave yam, water yam and yellow yam recorded 129.56 - 138.11, $133.58-$ 163.21 and $128.34-143.88$ respectively.

3. The white yam, purple yam, three leave yam, water yam and yellow yam respectively recorded $11.84-12.63,11.14-11.82,11.28-12.66,12.19-$ 12.38 and $11.6811 .96 \%$.

4. Three leaves yam recorded the highest water absorption capacity which makes it likely to have least shelf life stability because of the ability of absorbing water from a humid atmosphere.

\section{RECOMMENDATION}

There are over 600 varieties of yam of which 12 are edible in Africa, over $95 \%$ of these crops are grown in Africa. It is therefore recommend that further researches should be carried out on the other varieties of yams in order to come up with important data that will help the yam processors and food industries to improve and optimize their products and manufacturing process.

There are many other drying methods; It is also recommend that other researchers should embark on trying to use them in carrying out researches on yam drying in other to come up with more options and best yam drying method for processors.

Farmers and processors are advice to consider storing good percentage of yam meant for consumption inform of flour, to prolong shelf life and enhance usage. This will also help in eradication of post-harvest loses.

\section{REFERENCES}

[1] Bashirate A. Wahab, Abdul- Rasaq A. Adebowale, Silifat A. Sanni, Olajid P. Sobukola, Adewale O. Obadina, Olatundun E. Kajihausa, Mojisola O. Adegunwa, Lateef O. Sanni and Keith Tomlins (2015). Effect of Specie, pretreatments and drying methods on the functional and pasting properties of high quality Yam flour. Food Science and Nutrition (Open Access). 4(1):50 -58.

[2] Agwu A. E. and Alu J.I. 2005. Farmers perceived constraints to yam production in Benue State, Nigeria. Proceedings of the 39th Annual conference of the Agricultural society of Nigeria. pp. $347-350$ 
[3] Louis Schwaitz (2008) Accessed at www.renewableenergy world.com/articles/2008/05/ china-fuels-ethanol-industry-with-yams.

[4] FAO (2008) Faostat production 2008 data food and Agricultural organization, statistical Division htpp://www.fao.org/docrep1008/15287e/52860 bihtm.

[5]Internationsl Institute of tropical Agriculture .2013. 4RD review bulletin http://r4drevw.org/2013009/nigeria.release.improve.yamvaritesl

[6] IITA International Institute of Tropical Agriculture. 2009. Securing lively hoods through yam. Proc. of a technical workshop on progress in yam research or development in West and Central Africa, held in Accra, Ghana, FRAG TAG 704, IITA, Nigeria. pp. 329

[7] IITA. 2002.ResearchGinde55.http://r4drevw.org/2008004/Nigeria yam research article.

[8] Iduma F.O., Owombo P.T., U.B. Ighdaro. 2014. Economics of yam Production under Agro forestry system in sapoba forest Area, Edo State Nigeria. International Journal of Agriculture and Forestry 2014, 4(6): 440-445.

[9] Agriculture Nigeria .2014.Yam processing - Agriculture Nigeria. http:// agricultruenigerian.com/agro-proceesing/processing-of-crops/yam-processing.

[10] Akubor, P. 1, and Ukwuru, M. U. 2003. Functional properties and biscuit making potential of soybean and cassava flour blends. Plant Foods for Human Nutrition 58(3), 1-12.

[11] Nasir, M., Butt, M. S., Anjum, F. M., Jamil, A.,' and Ahmad, J. 2009. Physical and sensory properties of maize genii oil fortified cakes. Int. J. Agric. Biol. 11: 311-315.

[12] Chen M. J and Lin C.W, 2002. Factors affecting the water holding capacity of fibrinogen/ plasma protein gels optimized by response surface J. of food Science 67:2597-2582.

[13] Agama-Acevedoa E., Rosab A., Mendez-Montealvoa G. and Bello-Pereza L. 2008 Physicochemical and biochemical characterization of starch granules isolated of pigmented maize hybrid.Starch/Starke 60: 433-441.

[14] Abiodun, O. A. and Akinoso, R. 2014. Physical and functional properties of trifoliate yam flours as affected by harvesting periods and pre-treatment methods. Journal of Food Process Technology 5(2): $1-5$.

[15] Sittu, T. A., Dixon, A., Awonorin, S. O., Sanni, L. O. and Maziya-Dixon, B. 2008 Bread from composite cassava-wheat flour. II: Effect of cassava genotype and nitrogen fertilizer on bread quality. Food Research International 41(6), 569-578.

[16] Jackel, S. 1987. More wheat with superior baking quality is needed. Cereal Foods World 32(4): 323-325.

[17] Ezeocha V.C, Omodamiro, R. M., Oti, E., and Chukwu G. O. 2011. Development of trifoliate yam: cocoyam composite flour for fufu production. Journal of Stored Products and Postharvest Research 2(9): 184-188.

[18] Afoakwa, E. O., Budu, A. S., Asiedu, C., Chiwona-Karl tun, L. and Nyirenda, D. B 2012. Visco-elastic properties and physico-functional characterization of six high yielding cassava mosaic disease-resistant cassava (Manihot Esculenta Crantz) genotypes. Journal of Nutrition and Food Science 2:129. doi:10.4172/2155-9600.1000129.

[19] Rasper V. 1982. Theoretical Aspects of amylography. Ch. 1, Brabender Viscoamylograph Handbook.

[20] Eje B. E, Addo, A. A, and Dzisi, K. A. 2015. Effects of toasting time on Functional and -Visco-Elastic Properties of Cassava, Elour. IOSR Journal of Environmental Science, Toxicology and Food Technology (IOSR-JESTFT) 9(6): 01-06.

[21] Rasper, V. 1969. Investigations On starches from major starch crops grown in Ghana, 1: Hot Paste viscosity and gel-forming power. J. of Science Food and Agriculture 20:165.

[22] Onwuka G. I. 2005. food Analysis and Instrumentation: theory and practice Naptali Prints, Lagos pp. 156-161.

[23] Nwosu J. N.2010. Effect of soaking, Blanching and cooking on the anti-nutritional properties of Asaparagas beans flour. Nature and science J. 8 (a): 163 -167.

[24] Abbey B.W and Ibeh C. O. 1988. Functional Properties of raw and processed cowpea flour J. food Sci, 53.1988. Practitioners 1975-1977. 
[25] Onuegbu N. C. and Ojukwu M. 2013. Proximate functional and Anti Nutritional properties of Boiled Ukpo seed (Mucunaflagellipes) Flour. Nigeria food Journal Vol. 31 issue 1 2013, page 1-5.

[26] Leach. H.W., McCowen, L., and Schoch, T.J.1959. Structure of the starch granule.Swelling and solubility patterns of various starches. Cereal chemistry 36(6): 534-44.

[27] Ejeh Brendan Ekete. 2016. A Ph.D Dissertation (unpublished): Assessed at iv.knust.edu.gh., on $6^{\text {th }}$ july 2017 .

[28] Sathe, S. and Salunkhe, D.1981. Functional properties of the great northern bean (Phaseolus vulgaris.) proteins: emulsion, foaming, viscosity, and gelation properties. Journal of Food Science 46(1): 71-81.

[29] Adedeji, T., A. T. Hart, Tenkouan, I., Barimalaa, S. and Sanni S.O.2010. Comparative study of pasting prosperities of improved plantain, banana and cassava varieties with emphasis on industrial application. African J.of Food, Agriculture, Nutrition and Development 10(5):1-15.

[30] Sittu, T. A., Sanni, L. O., Awonorin, S. O., Maziya-Dixon, B. and Dixon, A. 2007.Use of multivariate techniques in studying the flour making properties of some CMD resistant cassava clones. Food Chemistry 101: 1606-1615.

\title{
UTICAJ METODA SUŠENJA NA FUNKCIONALNE OSOBINE JAM (Dioscorea Sp.) BRAŠNA
}

\author{
Chineze G. Okeke ${ }^{1 *}$ and Sylvester.I Oluka ${ }^{1}$ \\ ${ }^{1}$ Department of Agricultural \& Bioresource Engineering Enugu State University \\ of Science and Technology, Enugu State, Nigeria
}

Sažetak: Uticaj metode sušenja na funkcionalna svojstva pet različitih tipova brašna od Jam (Yam): belog, ljubičastog, žutog, vodenog i tri lišća, proučavan je metodom sušenja u peći i na suncu.

Funkcionalna svojstva su određena metodom odobrenom od AACC.

Rezultati ispitivanja su pokazali da je Beli tip Jam (Yam) ima opseg vlažnosti (WAC) od 173.22 do 181.31 secs, dok je ljubičasti varijetet Jam (Yam) imao opseg vlažnosti od: 151.69 do 201 secs. Tri preostala varijeteta jama, imali su respektivno raspon vlažnosti: 138.41 do 190.20 secs, a vodeni i žuti jam imaju zabeležen opseg vlažnosti od 143.62 do 182.11 secs i od 153.42 do 174.34 secs.

Rezultat istraživanja je takođe pokazao da beli Jam (Yam) beleži kapacitet upijanja vode (bubrenje) (VAC) u opsegu od 134.32 do 146.11 secs, dok je ljubičasti Jam (Yam) imao VAC opseg od 134.32 do 145.46. Napušteni varijeteti ove kulture: vodeni i žuti Jam (Yam) imale su vrednosti: 129.56 do 138.11; 133.58 do 163.21, i 128.34 do 143.88 secs. Pored toga, beli jam, purpurni jam, žuti jam su zabeležili respektivno raspon vlage bubrenja od: 11.84 do12.63; 11.14 do $11.82 ; 11.28$ do $12.66 ; 12.19$ do 12.38 i od 11.68 do 11.96.

Tri tipa brašna od Jam (Yam) kulture ostvarila su najveću sposobnost apsorpcije vode, zbog čega je verovatno da će imati najmanju stabilnost u odnosu na druge zbog sposobnosti apsorpcije vode iz vlažne atmosfere.

\footnotetext{
* Correspond Author. E-mail address: chinezeglory@yahoo.com
} 
Rezultati analize varijanse (ANOVA) o uticaju metoda sušenja na funkcionalna svojstva različitih varijeteta kulture Jam (Yam) pokazali su značajnu razliku na nivou verovatnoće od 5\% i 1\%, dok varijeteti kulture Jam (Yam) nisu pokazale značajne razlike u funkcionalnim svojstvima varijeteta brašna.

Ključne reči: metoda sušenja, funkcionalna svojstva, brašno jam, sposobnost kvašenja, apsorpcioni kapacitet.

Prijavljen:

Submitted:

20.05.2019.

Ispravljen:

Revised:

25.05.2019

Prihvaćen:

Accepted:

31.05 .2019 